INTERNATIONAL DESIGN CONFERENCE - DESIGN 2018

https://doi.org/10.21278/idc.2018.0105

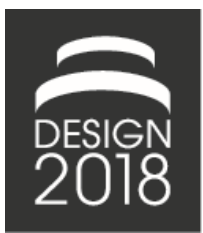

\title{
IDENTIFYING DISRUPTIVE TECHNOLOGIES: HORIZON SCANNING IN THE EARLY STAGES OF DESIGN
}

\author{
S. K. Ernstsen, C. Thuesen, L. R. Larsen and A. Maier
}

\begin{abstract}
Technology development is accelerating, driving disruption. Design is seen as key differentiator in creating innovative offerings but few design methods consider future technologies explicitly. In this article, we explore how a foresight method, namely horizon scanning, may be applied in a design context to anticipate disruption of construction. By means of a 3-step horizon scan, we identify 133 potentially disruptive technologies from across industries. We find that when preparing for disruption, design may benefit from the future-oriented and technology-focused features of horizon scanning.
\end{abstract}

Keywords: disruption, horizon scanning, technology development, design methods, digital design

\section{Introduction}

Disruption has become an important point on the agenda in established companies. Stories like the ones of Blockbuster being disrupted by the adoption of video streaming, or Kodak being disrupted by the introduction of digital cameras linger in the boardrooms. Such stories warn established companies to stay up-to-date on new technology and create "disruptive" solutions to avoid being disrupted themselves. When companies seek to stay competitive, design is often seen as a key differentiator (Samperi et al., 2002; Stevens and Moultrie, 2011). It is well acknowledged that the ability to design new products and services that satisfy the changing needs of customers is essential for companies to become and remain successful. However, as technological development accelerates, it is increasingly important for companies to look beyond the development of the immediate next product or service (Samperi et al., 2002). In that regard, applying future-oriented methods shows great potential, as these methods allow companies to prepare themselves for the changes anticipated and possibly also to act earlier (Malhotra et al., 2015).

The benefits from focusing on future markets and acting early is also found in disruption theory. Bower and Christensen (1995) coined the notion of 'disruptive technologies' in 1995. Since then, the term disruption has become widely used academically as well as among business practitioners to describe technologies that are able to up-end markets by changing the bases of competition (Danneels, 2004). In order to avoid being disrupted, Christensen argued that incumbent companies should invest in disruptive technologies at an early stage and adopt the new technology before it matures (Christensen, 1997). Furthermore, Bower and Christensen warn well-managed established companies against ignoring new technologies, just because they are not (yet) able to fulfil the needs of the current customers (Bower and Christensen, 1995). Instead they argue that focusing on future needs, markets and customers is essential when dealing with disruptive technologies. 
Drawing on these two points 1) the importance of investing in disruptive technologies while they are still immature and 2) the importance of predicting future needs, customers and markets, we argue that disruptive technologies are important to consider in the early phases of design. This is argued as the design process builds on technological opportunities as well as a thorough understanding of customers' needs - and the latter may well change when impacted by disruptive technology.

The potential benefits of applying future-oriented methods to design is not well described in design literature (Evans and Sommerville, 2007). Although designers may consider future as an intrinsic part of the design process, few design methods seem to focus on describing or imagining the future based on, for instance, trends and long-term technology development. Nevertheless, the fields of design and foresight have many similar characteristics, and in recent years the mutual benefits of translating methods and techniques for cross-fertilisation has gained attention from both fields (Rijkens-Klomp et al., 2017).

This article is guided by the following research question: How might horizon scanning be applied in the early stages of design to identify potentially disruptive technologies? We start by reviewing the notions of disruption and technology. Following this, the potential of using horizon scanning for early identification of disruptive technologies is outlined. To illustrate the potential, we present how horizon scanning was applied in the construction industry in the early stages of a design process; aiming at preparing the industry for disruptive changes. We end the article by reflecting on how design and foresight may cross-fertilise, and the usefulness of using horizon scanning for identifying disruptive technology is discussed.

\section{Disruptive technology}

\subsection{Disruption}

The theory of disruption provides an explanation to why well-managed companies fail in maintaining their market position when faced with new technology (Bower and Christensen, 1995; Christensen, 1997). The theory defines disruptive technology as opposed to sustaining technology and describes how disruptive technology "bring[s] to market a very different value proposition than had been available previously" (Christensen, 1997, p. xv). As Christensen has later emphasised, disruption should be understood as a process (Christensen et al., 2015). Typically, products based on disruptive technology enter a market offering low performance compared to the established counterparts in mainstream markets (Christensen, 1997). The disruptive technology tends to gain grounds among a new customer group - typically in the low-end of the current market - as the disruptive technologies generally are simpler and cheaper than established alternatives. As time passes, the disruptive technology develops and turns out to become competitive to the established products even in mainstream markets. In this way, established products are pushed off the market as the disruptive technology gradually gains more and more market shares.

The theory describes that disruption occurs because established companies tend to ignore disruptive technologies as long as the performance of these technologies is inferior to established products. However, arguing that technologies can develop faster than market demand, disruptive technologies that are underperforming today may actually satisfy the market tomorrow (Christensen, 1997). It is therefore important for incumbent firms to invest before the technology has matured enough to deliver a satisfactory performance in mainstream markets (Christensen, 1997).

Besides providing an explanation of why well-managed, established companies have lost significant market shares, the theory of disruption also provides guidelines for companies seeking to avoid being disrupted. According to the theory, incumbent companies should avoid evaluating the potential of disruptive technologies based on knowledge of current customer and markets. Instead the company should recognise that when dealing with disruptive technology, it is impossible to know the size of an emerging market, and instead apply a flexible discovery-based approach to evaluating market potential (Christensen, 1997). Moreover, the theory prescribes that the company should create an independent organisation and allocate resources to let this separate unit explore the potential of the disruptive technology. 
Realising that the source of disruption is not always technology, but may also be for instance a business model, Christensen has replaced the term disruptive technology with disruptive innovation (Christensen and Raynor, 2003). Moreover, the theory has been refined to distinguish between low-end disruption (targeting customers in the low-end of the current market) and new-market disruption (targeting current non-consumers) (Christensen and Raynor, 2003). Although this has broadened the applicability of the theory, it also has diluted the understanding of what disruptive innovation may or may not be (Danneels, 2004; Markides, 2006).

In order to identify disruption early, Christensen and Raynor (2003) suggest a job-to-be-done approach, focusing on what kind of job the customers "hire" the product to do. This is coherent with a typical usercentred design process (as seen in e.g. Thorpe et al., 2016). However, the challenges following a usercentred approach are those of users trying to foresee their own needs and wants in the future. And other challenges include the difficulty of selecting an appropriate user group, knowing that disruptive technology may well cause the customer base to change. Therefore we propose that a design process preparing for disruption may benefit from combining a user-driven approach with a technology-driven approach.

In this article, we focus on disruptive technologies in contrast to e.g. disruptive business models or disruptive innovation. By limiting our focus to technologies in this article, we seek to anticipate disruption from the technology development perspective that originally was used to form the theory of disruption. But first, let us specify what we mean by technology.

\subsection{Technology}

Although the term technology is broadly used and understood, the definition of technology is not as clear-cut as one might think. It may be easy to recognise that a computer, a pen and a lawnmower are instances of technology. However, the term technology is also used to describe methods, skills and knowledge used to create technological artefacts, such as laser-printing, calculating or manufacturing. These two dimensions of technology can be named technology as an artefact (Kline, 1985; Digironimo, 2011) and technology as a creation process (Digironimo, 2011).

Zooming out and comparing technology to other broadly applicable terms, such as science or culture, a third dimension of technology is revealed. Digironimo (2011) calls this third dimension technology as a human practice. This dimension views technology as an integral part of being human, since technology has existed since before we became homo sapiens (Kline, 1985). Kline adds to this by describing technology as a sociotechnical system of manufacturing and use, and argues that it "form [s] the physical bases of all human societies past and present" (Kline, 1985, p. 217).

For the purpose of this article, we find it necessary to limit the perspective on technology. In the search for potential disruption, we are interested in concrete technologies that may radically change the parameters of competition in a given market. This may be technologies in the form of artefacts (such as autonomous cars) or creation processes (such as 3D printing). However, for the purpose of this study, we will not reflect on how technology affects our society, in the sense of technologies as human practice. Examples of technology as human practice may include notions such as automation and circular economy, which in this context will be considered as trends rather than technologies.

It is characteristic for technologies that they evolve over time (Cozzens et al., 2010). This evolution is often depicted as an S-curve showing how an emerging technology starts as unproved technological potential and gradually matures as the technology finds suitable application(s) and settles in the market. As acknowledged by Cozzens et al. (2010, p. 364), it is "particularly important for a monitoring system to be able to detect emerging potentially disruptive technologies at the early stages of the cycle". Searching for technologies that will impact future markets, we are interested in technologies that are currently in the early stages of the S-curve, i.e. as they emerge and develop and before they mature. Mature technologies such as pencils and laser-printing are therefore not considered relevant for this study. Building upon the above description of disruption and technologies, we have provided a theoretical foundation for understanding the nature of disruptive technologies. Reviewing the theory of disruptive technology, Danneels (2004) proposed a need for understanding how potentially disruptive technologies can be identified. In the following, we will address this need by presenting horizon scanning as a suitable method for identifying disruptive technologies. 


\subsection{The need for a future-oriented approach}

Realising that in order to predict disruption, it is necessary to think about future technologies, needs and markets, it seems natural to look into the domain of technology foresight and forecasting in order to find a suitable identification method. However, the identification of disruptive technologies are not so easily caught by traditional forecasting methods (Cheng et al., 2017) or foresight (Dixon et al., 2014; Cheng et al., 2017). Most mainstream foresight and forecasting methods take their point of departure in the trajectories of technology development, and these methods are therefore much better at identifying the future development of sustaining technology than potentially disruptive. According to Georghiou and Harper (2013, p. 467) "dealing with disruptive transformations is seen as the key forward challenge for the practice of FTA [Future-Oriented Technology Analysis]."

Digitisation is often mentioned as a driver for disruptive changes (e.g. Wenzel et al., 2015; Stewart et al., 2017). Due to the lack of physical assets, digital solutions are less constrained by the typical boundaries of industries (Tilson et al., 2010). Taking this into account, it seems important for companies to be aware of technologies developing outside their own industrial domain. We therefore call for a broad method for identification of disruptive technologies across industries.

\subsection{Horizon scanning}

Corporate activities concerned with identifying new technologies is called technology intelligence. Kerr et al. (2006) have described four different technology intelligence modes that may be applied according to the needs and current knowledge of a company: mining, trawling, targeting and scanning. Although Kerr et al. (2006). argue that all four modes should be used concurrently, they also state that "Organisations in sectors experiencing high rates of technology change or at greater risk to disruptive technologies will employ the scan mode to a greater extent than the target mode". Moreover, if it is a managerial goal to understand what the company does not know that it doesn't know, a scanning mode is considered especially suitable. Considering that especially digital technologies create disruption across established industries, a cross-disciplinary and wide-ranging method such as horizon scanning is considered suitable.

Horizon scanning is a specific foresight method that is increasingly used by governments and private organisations to support decision making and policy development (Palomino et al., 2012).

Horizon scanning can be defined as "the systematic search for incipient trends, opportunities and constraints that might affect the probability of achieving management goals and objectives." (Sutherland et al., 2011, p. 10). Horizon scanning is normally based on desk research and obtaining knowledge from e.g. industry reports, government reports, scientific publications, patents, news articles, conferences and surveys in order to anticipate issues and opportunities of the future. As has been emphasised by Sun and Schoelles (2013), the choice of sources for a horizon scan should depend on the mandate and goals of the specific horizon scanning program.

It may be useful to differentiate between two types of horizon scanning: issue-centred and exploratory (Amanatidou et al., 2012). Issue-centred scanning seeks to evaluate a specific hypothesis, which the scanning activity seeks to confirm or question by means of a focused search. This corresponds to the target-mode of technology intelligence as described by Kerr et al. (2006). In contrast, an exploratory scanning aims at identifying a long list of emerging issues, e.g. by examining at lot of topics from various sources and domains. Often both approaches are used interchangeably in different phases of the project, based on the objective of the scanning activity. Kerr et al. (2006) recommend a migration from the more exploratory scan mode to a target mode, where the benefits of specific technologies are investigated in detail.

As the future is unknown, it is hard to validate the results of a horizon scan before time has passed, revealing to what extent the predictions about future technological development turned out to be correct. Nevertheless, we argue that in order to prepare for disruptive changes, it is better for a company to have identified a broad range of technologies, of which some may show to be unimportant, than the opposite case of not having spotted a technology that turns out important. To illustrate the potential of using horizon scanning for anticipating disruption, we will now describe how we researched and used horizon scanning in the construction industry to identify new and potentially disruptive technologies. 


\section{Applying horizon scanning in the construction industry}

\subsection{The construction industry}

To examine empirically how disruptive technologies may be anticipated by means of a horizon scan, we chose to take the point of departure in a specific industry, namely the Danish construction industry. This industry was chosen, as it faces a large number of multi-faceted challenges that may be tackled as design problems. Moreover, the industry is often described as conservative (Fuhr et al., 2009) also when it comes to adopting new technologies, and consequently the threat of disruption may no longer be hypothetical. Productivity of Danish construction has decreased with $0.5-1 \%$ per year in the period from 1995 to 2011, despite massive digitalisation and technological developments in these years. As comparison, the manufacturing industry increased its productivity with more than $2 \%$ per year in the same 16 year period, whereas the finance and insurance industry experienced an impressive productivity increase of 5.6\% per year (DI's produktivitetspanel, 2013).

The low productivity of the construction industry is also a global challenge, which has led several analysts to conclude that the construction industry is now ripe for disruption (e.g. World Economic Forum, 2016; McKinsey Global Institute, 2017). Root causes include complex regulation, little crossfunctional collaboration, lack of innovation, large dependency of public-sector demand, and a mismatch between risk and reward in contractual structures (World Economic Forum, 2016; McKinsey Global Institute, 2017). This results in building projects being poorly managed, taking longer than planned and surpassing their budget.

Global investments in construction technology has increased in recent years with 183\% from 2014 to 2016 (Tracxn, 2017), suggesting that technologies will play an increasingly important role in the construction industry in the future. Considering how other industries, such as the automotive industry, have been radically transformed by the advent of disruptive technologies, there is arguably a good reason for construction companies to act proactively in this regard (World Economic Forum, 2016). From a construction company's point of view, there is a need for engaging in a design process aimed at utilising the opportunities of new technologies. We consider the future-oriented scope of horizon scanning to be especially helpful in this regard.

\subsection{Horizon scanning in three steps}

We conducted the horizon scanning activity in three steps, as illustrated in Table 1.

The first step, 'Defining', was to create a foundation for the horizon scan. First, we clarified purpose, target group, desired outcome and expected format. The purpose of the horizon scanning activity was to identify new technologies that would be relevant for an established company in the construction industry to consider when preparing the company for disruptive changes. In this regard, it was considered important to identify technologies broadly and across industrial domains without initial considerations regarding relevance to the construction industry. This meant that e.g. biomedical technologies (such as DNA writing) and space technologies (such as nanosatellites) were not considered any different from technologies developing within the construction industry (such as 3D printing concrete). This was done to keep an open-mind as to how the construction industry might benefit from any technological development, seeking to use this knowledge to create or predict disruptive opportunities.

More specifically, the desired outcome was described as a long list or a catalogue of emerging and potentially disruptive technologies. The primary target groups were managers and stakeholders from Danish construction companies interested in business development and/or preparing for disruption. The focus was on technologies in contrast to e.g. observed changes or potentially disruptive business models. Due to time constraints, a snapshot of emerging technologies was preferred as opposed to continuous or repeated horizon scanning. Considering the purpose of this horizon scanning, we decided to use an exploratory scanning approach looking for signals of emerging technologies across a wide range of sources. 
Table 1. The horizon scanning was conducted in three steps

\begin{tabular}{|c|c|c|}
\hline 1. Defining & $\begin{array}{l}\text { Clarification of } \\
\text { - Purpose } \\
\text { : } \text { Target group } \\
\text { - Expired outcome } \\
\text { Expected format }\end{array}$ & $\begin{array}{l}\text { Identification of relevant sources } \\
\text { : } \quad \text { Foresight reports } \\
\text { : Industrs analyst reports } \\
\text { - Conferences }\end{array}$ \\
\hline 2. Identifying & $\begin{array}{l}\text { Scanning of literature } \\
\text { - Manual identification of } \\
\text { technologies in reports } \\
\text { Marking which sources the } \\
\text { technologies were found in }\end{array}$ & $\begin{array}{l}\text { Conference participation } \\
\text { - Manual identification of } \\
\text { techunologies being presented } \\
\text { - Marking which conference a given } \\
\text { technology was found }\end{array}$ \\
\hline 3. Synthesising & \multicolumn{2}{|c|}{$\begin{array}{l}\text { Organisation of technologies } \\
\text { - Identifying synonymous } \\
\text { technologies } \\
\text { - Organising technologies based on } \\
\text { frequency }\end{array}$} \\
\hline
\end{tabular}

The foundation for the horizon scanning was laid out by collecting relevant reports. We identified relevant foresight reports to ensure that the horizon scanning was based on previous, thorough and broad horizon scanning activities conducted by e.g. governmental institutions. Moreover, we included reports from business analysts Gartner, IDC, and Forrester. These three business analysts have the largest influence on European customers as well as the most media coverage and financial attention among all industry analysts in the world (Ikeler, 2007; Dotsika and Watkins, 2017). Finally, we found industry reports that focused especially on the construction industry to ensure the identification of technologies from the targeted industry. All reports were based on comprehensive research and were independent of commercial interests. Considering that the target group was Danish, as well as the fact that technologies develop across country borders, we ensured that both Danish and international sources were represented. Furthermore, we identified 9 industry conferences and seminars targeted at participants from either construction, media, healthcare, $\mathrm{R} \& \mathrm{D}$ or technology-savvy people in general. The conferences/ seminars were included, if they had one or more presentations on currently developing technologies. In total, 11 reports and 9 conferences were included as sources, see Table 2.

Table 2. Sources for the horizon scanning

\begin{tabular}{|c|l|l|}
\hline Count & Type of source & Description \\
\hline 2 & Foresight reports & By public authorities - EU and Denmark \\
\hline 6 & Technology reports & By Gartner, IDC, Forrester, McKinsey \& Co., CB Insights \\
\hline 3 & $\begin{array}{l}\text { Industry-specific reports on } \\
\text { the construction industry }\end{array}$ & By World Economic Forum, McKinsey \& Co., Tracxn \\
\hline 3 & $\begin{array}{l}\text { Construction } \\
\text { conferences/seminars }\end{array}$ & $\begin{array}{l}\text { Themes: 3D printed construction, virtual design construction, annual } \\
\text { construction seminar }\end{array}$ \\
\hline 1 & R\&D conference & Future Festival \\
\hline 1 & Media conference & NextM \\
\hline 2 & Healthcare seminars & Themes: disruption, blockchain \\
\hline 2 & Technology conferences & Technomania, SingularityU Denmark \\
\hline
\end{tabular}

The second step 'Identifying' was to identify technologies. For that, we reviewed the 11 reports and identified emerging technologies described in the reports. This resulted in a long list of technologies. For each technology, we noted in which sources which the specific technology was mentioned. Furthermore, we participated in 9 industry conferences and seminars to obtain information from business and technology experts. Through presentations at the conference, we identified additional technologies and trends, which were added to the list. Again we noted at which conference we had heard about the technologies.

In the third step 'Synthesising', we went through the list of technologies. We found that some technologies could be defined as a subset of another technology on the list (e.g. machine learning and artificial 
intelligence), while other technologies were overlapping to some extent (e.g. Building Information Modelling and Virtual Design Construction). In some cases, we found that two terms were used interchangeably about the same basic technology (e.g. additive manufacturing and 3D printing, or wireless technology and 5G). In these cases, we considered both notions to describe one technology and combined them on the list. Next, we counted the number of times that a specific technology had been found across the 20 sources (11 reports and 9 conferences). We then organised the list based on frequency counts so that those technologies that had been found the most were placed at the top of the list.

\subsection{Findings}

All in all, we identified 133 technologies across industries. These can be seen in Table 3, where they are sorted based on the number of times each technology was found.

When evaluating technologies based on the number of times they occur, it is important to take into account that some of the listed technologies may be used as umbrella terms covering several other technologies on the list. This may result in umbrella terms being found more often than a specific subset technologies. Moreover, the current hype of certain technologies may also affect the number of times a specific technology is found. This may, for example, be the case for blockchain technology, which is a relatively new technology currently peaking on Gartner's Hype Curve (Furlonger et al., 2017). Nevertheless, we consider the number of times a technology has been found as a good proxy for understanding which technologies it will be hard to avoid when looking into the future.

\subsection{Validation of findings}

To deepen our understanding of technological impact in the future - and as a way of validating the results above - we conducted short interviews with 25 participants attending three conferences. These participants were all interested in technological development and represented a broad selection of different industries (e.g. digital marketing, transportation and hotel). We asked the participants which technology (or trend) they thought would have the biggest impact on the development of our society during the next 10 years. The results are seen in Table 4. (Some participants mentioned more than one technology, and the total sum of answers from 25 participants therefore sums to 27.)

Comparing the answers to the results of the horizon scan (Table 3), we see that all the technologies mentioned by the participants was also found in the horizon scan. This suggests that the most commonly found technologies from the horizon scan are also considered important by technology-savvy stakeholders across industries. Moreover, we find that 8 out of 10 technologies mentioned in the interviews are found 7 times or more in the horizon scan. We therefore suggest that the technologies at the top of Table 3 are especially important to be aware of when preparing for disruptive changes.

As can be seen from Table 3, the five technologies that were found the most were: Internet of things, artificial intelligence, big data analytics, robots and blockchain. This suggests that these technologies are especially important to integrate in a disruption-proactive design process.

Applying the identified technologies in a business development-oriented design process could entail questions like "Who might benefit from internet of things and the connected functionality it provides?", "How might artificial intelligence substitute one or more tasks in our industry?" or "What kind of data has value, we ought to utilize more, e.g. by means of analytics?". In this way the list may act as a possible solution list, for which the designer (in this case, business developers and policy makers in the construction industry) may not yet know the problem.

Although few of the technologies on the list are specific to the construction industry, it was possible to think of use cases in the construction industry for most of the technologies. We found that most of the reports and conferences that were specifically focusing on technologies used in construction did not pay much attention to the generic technologies emerging in other industries, such as blockchain or artificial intelligence. Presenting the results of the horizon scan to stakeholders in the construction industry, we found that it raised the awareness of the current technological development happening across industries, and ignited conversations about possible future development. The horizon scan facilitated questions like "How might we use the blockchain technology in our industry?" instead of focusing only on technologies that have already proven useful in construction. In this way, the horizon scan facilitated an open-minded conversation about how construction may be disrupted by new technology. 
Table 3. The identified 133 technologies organised based on the number of times the technologies were found in 20 sources

\begin{tabular}{|c|c|c|c|}
\hline Count & \multicolumn{3}{|c|}{ Technologies } \\
\hline 14 & Internet of things & & \\
\hline 13 & Artificial intelligence & & \\
\hline 12 & Big data analytics / business analytics & & \\
\hline 11 & Robots & & \\
\hline 10 & Blockchain & & \\
\hline 9 & Virtual reality & Additive manufacturing / 3D printing & \\
\hline 8 & Autonomous vehicles & Deep learning algorithm & Machine leaming \\
\hline 7 & Augmented reality & $\begin{array}{l}\text { Voice control/ Natural language processing/ } \\
\text { conversational user interface }\end{array}$ & \\
\hline & Cloud computing & Mobile connectivity / Wireless / 50 & Drones / UAVs \\
\hline 6 & $\begin{array}{l}\text { Virtual personal assistants / smart advisor / chat } \\
\text { bot/cognitive expert advisor } \\
\text { Quantum computing }\end{array}$ & & Synthetic biology \\
\hline 5 & $\begin{array}{l}\text { Smait city } \\
\text { Bioinformatics }\end{array}$ & Building Information Modelling (B|M) & Connected transport / Smart transport \\
\hline 4 & $\begin{array}{l}\text { Battery technology, e.g. lithium-ion } \\
\text { Wind and solar power } \\
\text { Health monitoring wearables or implants / } \\
\text { Personal health screening } \\
\text { Human augmentation/Augmented sensing } \\
\text { Brain-computer interface/Implantable direct } \\
\text { neural interface }\end{array}$ & $\begin{array}{l}\text { Generative Design } \\
\text { Bitcoins }\end{array}$ & $\begin{array}{l}\text { Cognitive computing } \\
\text { Carbon nanotubes / graphene } \\
\text { Genome editing, e.g.CRISPR }\end{array}$ \\
\hline 3 & $\begin{array}{l}\text { Biofuels } \\
\text { Carbon capture and storage } \\
\text { Virtual customer assistants } \\
\text { Personal identity and data mngt. } \\
\text { Serverless services (Paa5, laa5, 5aa5) } \\
\text { Edge computing } \\
\text { Photonic computing } \\
\text { Prefabricated volumetric construction / Modular } \\
\text { construction } \\
\text { Tissue engineering / Augmented biostructure } \\
\text { Neuromorphic hardware / Neurosynaptic chip }\end{array}$ & $\begin{array}{l}\text { Computer vision / machine vision } \\
\text { Emotion recognition } \\
30 \text { printing construction } \\
\text { Self-cleaning surfaces } \\
\text { Functional materials } \\
\text { Self-healing materials eg. concrete } \\
\text { Exo-skeletons / Augmented mobility }\end{array}$ & $\begin{array}{l}\text { Predictive diagnosis based on genes } \\
\text { DNA writing } \\
\text { DNA sequencing } \\
\text { Personalised medicine } \\
\text { Biochips and biosensors } \\
\text { Project lifecycle management } \\
\text { Construction robots } \\
\text { Machine-to-machine-communication } \\
\text { Neuroprosthetics } \\
\text { Modelling simulation and gaming }\end{array}$ \\
\hline 2 & $\begin{array}{l}\text { Real-time weather data } \\
30 \text { scanning } \\
\text { Cellular agriculture/ synthetic food } \\
\text { Electric vehicles } \\
\text { Fuel cells } \\
\text { Fossil fuel exploration and recovery } \\
\text { Nuclear fusion } \\
\text { Augmented data discovery } \\
\text { loT analytics incl. location analytics } \\
\text { Augmented analytics } \\
\text { Micropayment } \\
\text { Nanomaterials } \\
\text { Smart contracts }\end{array}$ & $\begin{array}{l}\text { Machines in charge of own money } \\
\text { Parallel or grid computation } \\
\text { DNA computing } \\
\text { Mixed reality } \\
\text { Volumetric display } \\
\text { 5mart dust } \\
\text { Digital twin } \\
\text { Wearable or implantable translators } \\
\text { Humanoide robots } \\
\text { Nano-bots / Nanodevices in healthcare } \\
\text { Self-assembling/organizing structure } \\
\text { Precision agriculture/precision farming/ } \\
\text { site-sperifir r-rop management }\end{array}$ & $\begin{array}{l}\text { Genetic engineering } \\
\text { Regenerative medicine } \\
\text { Biocatalysis } \\
\text { Smart infrastructure } \\
\text { Hyperloop } \\
\text { Virtual Design Construction } \\
\text { Flying cars } \\
\text { Construction marketplace /e-auction } \\
\text { Micro and Nano satellites } \\
\text { Space transport } \\
\text { Colonization of space }\end{array}$ \\
\hline 1 & $\begin{array}{l}\text { Accurate GPS data } \\
\text { Smart countryside } \\
\text { Power microgeneration } \\
\text { Off-the-grid / autonomous building } \\
\text { Smart grid } \\
\text { Advanced water purification } \\
\text { Digital agriculture (GMO } 3.0) \\
\text { Coating food to extend shelf life } \\
\text { Marine and tidal power } \\
\text { Harvesting energy from space } \\
\text { Energy from human motion } \\
\text { Hydrogen Energy } \\
\text { Automated bulldozers and autonomous haul } \\
\text { trucks }\end{array}$ & $\begin{array}{l}\text { Autorouting } \\
\text { Data mining } \\
\text { Enterprise taxonomy /ontology mngt. } \\
\text { Software-Defined Security (SDS) } \\
\text { Citizenscience } \\
\text { RFID tags } \\
\text { Surface computing } \\
\text { Biometric identification } \\
\text { Metamaterials } \\
\text { Piezoelectric materials } \\
\text { Collaborative robots } \\
\text { Autonomous delivery robots }\end{array}$ & $\begin{array}{l}\text { Real-time diagnostics support } \\
\text { Medical and bio imaging } \\
\text { Stem cells } \\
\text { Smart building } \\
\text { Data driven facility management } \\
\text { Smart workplace } \\
\text { Accident prediction and prevention } \\
\text { Smart robots } \\
\text { Biomimetrics / nature-inspired design } \\
\text { Circular construction } \\
\text { Geo-engineering } \\
\text { Robotic process automation } \\
\text { Nuclear fission }\end{array}$ \\
\hline
\end{tabular}


Table 4. The technologies that 25 interviewed participants thought would have the biggest impact on our society in the next 10 years

\begin{tabular}{|c|l|c|l|}
\hline No. of answers & Technologies & No. of answers & Technologies \\
\hline 6 & Artificial intelligence & 2 & Blockchain \\
\hline 6 & Virtual reality & 1 & Augmented humans \\
\hline 4 & Internet of things & 1 & Autonomous cars \\
\hline 3 & Augmented reality & 1 & Nanotechnology \\
\hline 2 & Big data & 1 & Voice controlled interfaces \\
\hline
\end{tabular}

Many of these technologies are to a large extent digital. Recalling that digitisation is a driver for disruptive change, we suggest that the degree to which a technology is digital is an important factor to be aware of when seeking to anticipate disruption. This relation would be interesting to examine in further work. Further work might also include exploring the potential of specific technologies from the list and discovering suitable application areas. This corresponds to a migration from the scan mode to the target mode, which is recommended by Kerr et al. (2006). The potential of a specific technology might be explored through an innovative design process, which is able to translate between different industrial domains and take the user perspective into account. Exploring different application areas for the same technology may benefit the design process as well as inform and qualify the foresight process.

\section{Discussion}

In the following, we will start by discussing the applicability of the horizon scanning method. Next, we will discuss implications of applying the method for identifying disruptive technologies in construction, to what extent this may transfer to other industries, and how design may benefit from it.

As shown above, horizon scanning used for exploratory purposes enables the identification of a large number of technologies while they are still in the early phases of development. This allows companies to gain the kind of first-mover advantage that according to Christensen (1997) is necessary when dealing with disruptive technologies. Nevertheless, the horizon scanning method also has some limitations. The method has been criticised for its superficial "scattergun approach" that does not reveal the implications of (or linkages between) different technologies (Georghiou and Harper, 2013, p. 468). Furthermore, it is arguably difficult for a company to take investment decisions based on the long list of emerging technologies without guidance towards the level of disruptive potential of the listed technologies. Not knowing the exact potential of the listed technologies may though also be seen as a strength of using horizon scanning in preparing for disruption. This is argued as the potential of disruptive technologies is inherently difficult to predict compared to the potential of sustainable technologies (Christensen, 1997). Nevertheless, supplementing the exploratory scan with an issue-centred scan may be necessary industrial context to provide a sufficient foundation for decision making.

One might argue that identifying disruptive technologies is only one small step in preparing a company or an industry for disruption. We agree. Not every technology on the list represents an opportunity or threat to the target company/industry, and there is considerable work in selecting the best technological opportunity and developing it so it fits with the context, generates profit and satisfies customers. It is also necessary to take a lot of industry-specific factors into account, e.g. current processes, stakeholders, roles, regulations, or business model opportunities. However, developing an industry or company to prepare for disruption, it is important not to let the immediate challenges be a barrier for development. Instead of defining customers, competitors, offerings and industry boundaries in advance, horizon scanning encourages the target group to think about the future, see new links and translate ideas from one industrial domain to another. This also means that the result of the horizon scan is generic. We have shown how the method was applied in the construction industry; nevertheless, only few technologies on the list are construction-specific. This suggests that the results may also be valuable in other industries beyond construction.

Looking through the list of technologies, we found that the technologies on the rise in construction (e.g. Building Information Modelling or 3D printing construction) were typically not mentioned in the generic sources focusing on emerging technologies. We therefore found it valuable that we had 
explicitly searched for sources focusing on construction technologies as a part of step 1 in the horizon scan. Transferring this horizon scanning method to another industry, we suggest it may be useful to include sources that focus specifically on technological development of the industry sector in question. Preparing for disruption is not a clear-cut task. Nevertheless, disruption theory as well as other theories (e.g. Ismail et al., 2014) agree on the importance of experimenting with the emerging technologies in order to identify their potential. From a business administration point of view, Christensen (1997) advises companies to apply a discovery-driven approach where (potentially) disruptive technology should be introduced in the market in a small-scale and easy modifiable version. From a design perspective, this corresponds to an iterative and experimental design process that is adaptive to stakeholder responses.

Design processes are typically seen as a co-evolution of problem and solution (Dorst and Cross, 2001). We argue that horizon scanning can aid the exploration the solution-space, as the listed technologies represent different possible or impossible solutions to a design problem. However, one might also argue, that the technologies represent various problems of the future that needs to be tackled through design. Although we cannot be fully be sure that the identified technologies will turn out to create disruption, we argue, that identification in itself will benefit the design process, as it allows for an open-minded approach to what might be. The horizon scanning method differs from other design methods that systematically explore possible solutions to a design problem (e.g. QFD, morphological charts), because it takes point of departure in a design problem that is not (yet) known. We therefore see horizon scanning as a good supplement to a problem-exploring approach, where e.g. stakeholders are involved in explaining what is and imagining what could be. By creating awareness of future scenarios and potential solutions, the horizon scanning method may aid the designer in anticipating future design problems and in working towards sustainable futures. And keeping in mind that technologies can develop faster than market demand, we argue that the ability to foresee future challenges is an essential part of preparing for disruption.

\section{Concluding remarks}

Preparing for disruption is on the top of the agenda in many industries. This affects the design of new products and services, as companies strive to stay on top of technological advancements. In this article, we have shown how the foresight method horizon scanning may be used to identify new technologies with disruptive potential. We have reviewed the notions of disruption and technology, presented the horizon scan method, and shown how applying the method in the construction industry led to the identification of 133 technologies. The identified technologies is developing in different industries such as healthcare, space and IT. The cross-industrial approach ensures that traditional industry boundaries does not limit the design of disruptive ideas, which arguably is important when preparing for disruption. This article contributes to both practice and research. For practice, we have described a three-step process for conducting a horizon scan, and hereby identified 133 potentially disruptive technologies. For research, we have argued for the relevance of applying of horizon scanning in design and demonstrated how horizon scanning may be applied in the early stages of design in order to anticipate disruptive technologies.

\section{References}

Amanatidou, E., Butter, M., Carabias, V., Könnölä, T., Leis, M. et al. (2012), “On concepts and methods in horizon scanning: Lessons from initiating policy dialogues on emerging issues”, Science and Public Policy, Vol. 39 No. 2, pp. 208-221. https://doi.org/10.1093/scipol/scs017

Bower, J. and Christensen, C.M. (1995), "Disruptive technologies - catching the wave", Harvard Business Review, Vol. 73 No. 1, pp. 155. https://doi.org/10.1016/0024-6301(95)91075-1

Cheng, Y., Huang, L., Ramlogan, R. and Li, X. (2017), "Forecasting of potential impacts of disruptive technology in promising technological areas: Elaborating the SIRS epidemic model in RFID technology", Technological Forecasting and Social Change, Vol. 117, pp. 170-183. https://doi.org/10.1016/j.techfore.2016.12.003

Christensen, C.M. (1997), The innovator's dilemma: When new technologies cause great firms to fail, Harvard Business Review Press, Boston.

Christensen, C.M. and Raynor, M.E. (2003), The Innovator's Solution: Creating and Sustaining Successful Growth, Harvard Business School Publishing Corporation. 
Christensen, C.M., Raynor, M. and McDonald, R. (2015), "What is disruptive innovation?”, Harvard Business Review, pp. 44-53.

Cozzens, S., Gatchair, S., Kang, J., Kim, K.-S., Lee, H.J. et al. (2010), "Emerging technologies: quantitative identification and measurement", Technology Analysis \& Strategic Management, Vol. 22 No. 3, pp. 361-376. https://doi.org/10.1080/09537321003647396

Danneels, E. (2004), "Disruptive Technology Reconsidered: A Critique and Research Agenda”, Journal of Product Innovation Management, Vol. 21 No. 4, pp. 246-258. https://doi.org/10.1111/j.07376782.2004.00076.x

DI's produktivitetspanel (2013), Produktivitetsforskelle på tvars af brancher. [online] Available at: https://di.dk/SiteCollectionDocuments/Opinion/Konjunktur/Produktivitetsforskelle på tværs af brancher.pdf

Digironimo, N. (2011), "What is Technology? Investigating Student Conceptions about the Nature of Technology", International Journal of Science Education, Vol. 33 No. 10, pp. 1337-1352. https://doi.org/10.1080/09500693.2010.495400

Dixon, T., Eames, M., Britnell, J., Butina Watson, G. and Hunt, M. (2014), "Urban retrofitting: Identifying disruptive and sustaining technologies using performative and foresight techniques", Technological Forecasting \& Social Change, Vol. 89, pp. 131-144. https://doi.org/10.1016/j.techfore.2013.08.027

Dorst, K. and Cross, N. (2001), "Creativity in the Design Process: Co-Evolution of Problem-Solution", Design Studies, Vol. 22 No. 5, pp. 425-437. https://doi.org/10.1016/s0142-694x(01)00009-6

Dotsika, F. and Watkins, A. (2017), "Identifying potentially disruptive trends by means of keyword network analysis", Technological Forecasting \& Social Change, Vol 119, pp. 114-127. https://doi.org/10.1016/j.techfore.2017.03.020

Evans, M. and Sommerville, S. (2007), "Design Led Futures: Futures Thinking in the Design Curriculum", Proceedings of ConnectED 2007: International Conference on Design Education, Sidney.

Fuhr, K., Bang, H.L., Beim, A., Haugbølle, K., Møller, J.S. et al. (2009), Fremtidens byggeerhverv $i$ et globaliseringsperspektiv, ATV - Akademiet for de Tekniske Videnskaber.

Furlonger, D., Valdes, R. and Kandaswamy, R. (2017), Hype Cycle for Blockchain Technologies, 2017, Gartner.

Georghiou, L. and Harper, J.C. (2013), "Rising to the challenges-Reflections on Future-oriented Technology Analysis", Technological Forecasting and Social Change, Vol. 80 No. 3, pp. 467-470. https://doi.org/10.1016/j.techfore.2012.10.009

Ikeler, A. (2007), "The Under-Examined Public: Making Sense of Industry Analysts and Analyst Relations", Journal of Promotion Management, Vol. 13 No. 3-4, pp. 233-260. https://doi.org/10.1080/10496490802307051

Ismail, S., Malone, M.S. and van Geest, Y. (2014), Exponential Organizations: Why new organizations are ten times better, faster and cheaper than yours (and what to do about it), Diversion Books, New York.

Kerr, C.I.V., Mortara, L., Phaal, R. and Probert, D.R. (2006), “A conceptual model for technology intelligence”, International Journal of Technology Intelligence and Planning, Vol. 2 No. 1, pp. 73. https://doi.org/10.1504/IJTIP.2006.010511

Kline, S.J. (1985), “What Is Technology?”, Bulletin of Science, Technology \& Society, Vol. 5 No. 3, pp. $215-218$. https://doi.org/10.1177/027046768500500301

Malhotra, S., Das, L.K. and Chariar, V.M. (2015), "Classification of forecasting methods with respect to their structure", Proceedings of The Third International Conference on Design Creativity, pp. 148-157.

Markides, C. (2006), "Disruptive Innovation: In Need of Better Theory*", Journal of Product Innovation Management, Vol. 23 No. 1, pp. 19-25. https://doi.org/10.1111/j.1540-5885.2005.00177.x

McKinsey Global Institute (2017), Reinventing Construction: A Route To Higher Productivity. [online] McKinsey Quarterly. Available at: http:/www.mckinsey.com/industries/capital-projects-and-infrastructure/ourinsights/reinventing-construction-through-a-productivity-revolution

Palomino, M.A., Bardsley, S., Bown, K., De Lurio, J., Ellwood, P. et al. (2012), "Web-based horizon scanning: concepts and practice", Foresight, Vol. 14 No. 5, pp. 355-373. https://doi.org/10.1108/14636681211269851

Rijkens-Klomp, N., Baerten, N. and Rossi, D. (2017), "Foresight for debate: Reflections on an experience in conceptual design”, Futures, Vol. 86, pp. 154-165. https://doi.org/10.1016/j.futures.2016.11.008

Samperi, J., Hollins, B. and Holdway, R. (2002), "Finding tomorrow today", Proceedings of DESIGN 2002, the 7th International Design Conference, pp. 689-694.

Stevens, J. and Moultrie, J. (2011), “Aligning strategy and design perspectives: A framework of design's strategic contributions", The Design Journal, Vol. 14 No. 4, pp. 475-500. https://doi.org/10.2752/175630611X13091688930525

Stewart, B., Schatz, R. and Khare, A. (2017), "Making Sense of Digital Disruption Using a Conceptual Two-Order Model”, In: Khare, A., Stewart, B. and Schatz R. (Eds.), Phantom Ex Machina, Springer, Cham, pp. 3-21. https://doi.org/10.1007/978-3-319-44468-0_1 
Sun, F. and Schoelles, K. (2013), A Systematic Review of Methods for Health Care Technology Horizon Scanning. [online] Rockville, MD. Available at: https://effectivehealthcare.ahrq.gov/topics/horizon-scan/research-2013

Sutherland, W.J., Bardsley, S., Bennun, L., Clout, M., Côté, I.M. et al. (2011), "Horizon scan of global conservation issues for 2011", Trends in Ecology and Evolution, Vol. 26 No. 1, pp. 10-16. https://doi.org/10.1016/j.tree.2010.11.002

Thorpe, J.R., Rønn-Andersen, K.V.H., Bień, P., Özkil, A.G., Forchhammer, B.H. and Maier, A.M. (2016), "Pervasive assistive technology for people with dementia: a UCD case", Healthcare Technology Letters, Vol. 3 No. 4, pp. 297-302. https://doi.org/10.1049/htl.2016.0057

Tilson, D., Lyytinen, K. and Sørensen, C. (2010), "Digital Infrastructures: The Missing IS Research Agenda", Information Systems Research, Vol. 21 No. 4, pp. 748-759. https://doi.org/10.1287/isre.1100.0318

Tracxn (2017), Construction Tech Startup Landscape. [online] Tracxn Technologies Private Limited. Available at: https://www.slideshare.net/Tracxn/tracxn-research-construction-tech-landscape-february-2017 (accessed: 08.12.2017).

Wenzel, M., Wagner, D., Wagner H.-T. and Koch, J. (2015), "Digitization and Path Disruption: An Examination in the Funeral Industry", ECIS 2015 Completed Research Papers. https://doi.org/10.18151/7217523

World Economic Forum (2016), Shaping the Future of Construction: A Breakthrough in Mindset and Technology. [online]

Available

at: https://www.bcgperspectives.com/Images/Shaping_the_Future_of_Construction_may_2016.pdf

Sidsel Katrine Ernstsen, PhD student

Technical University of Denmark, Management Engineering, Engineering Systems

Toften 28, 3450 Allerød, Denmark

Email: sern@dtu.dk 